\title{
The Querist and the Development of George Berkeley's Understanding of Society
}

DOI: http://dx.doi.org/10.12775/RF.2016.042

In the years 1735-1737, first in Dublin and subsequently in London, an Irish philosopher George Berkeley (1685-1752) published The Querist, a three-piece treatise on economics. In 1750-1752, new editions which appeared in Dublin, Glasgow, and London followed, slightly modified. The popularity of the work can be ascribed to its actual topic - the Querist depicted the disastrous economic situation in Ireland and pointed at possible improvements. Although it was the first time Berkeley focused on economics to such an extent and detail, several of his earlier writings were devoted to social issues: the Passive Obedience (1712; hereafter PO), An Essay Towards Preventing the Ruin of Great Britain (1721; hereafter ER), and the Alciphron (1732). However, what constitutes a current issue at one time, later frequently sinks into the past and becomes forgotten: the significance of these works was overshadowed by his theoretical works, especially the earlier ones, such as A Treatise concerning the Principles of Human Knowledge (1710) and the Three Dialogues (1712). Also the last extensive work by Berkeley, Siris (1744), in which he developed a new philosophy of nature but combined it with a detailed description of the supposed universal curative properties of tar-water, was long neglected by scholars. Thus, in the common reception, Berkeley's philosophy began to be interpreted as a coherent whole whose main motif, i.e. immaterialism, was found in the Principles and the Dialogues. Even if more detailed studies raised doubts concerning its perfect invariability and initiated discussions on its possible development or even radical changes and 
turns ${ }^{1}$, Berkeley did not change his mind even later, at least according to the opinion shared by the majority of historians.

Recent research into Berkeley's thought at its earliest stage ${ }^{2}$ as well as in the late period (especially Siris ${ }^{3}$ ) have undermined the dogma of fundamental immutability of Berkeley's philosophy with its main motifs, namely the immaterialistic metaphysics and the treatment of philosophical theories as theological arguments. According to the approach, the most significant change occurs in the later period in which Berkeley adopted a new metaphysics of light and seems to have abandoned his immaterialistic standpoint. ${ }^{4}$ All this casts a shadow on the image of Berkeley's uniform and unchanging philosophy. Nonetheless, the Querist, which represents the same period, although devoted to economic issues, seems perfectly inscribed in Berkeley's earlier theoretical views. Here, the Irish philosopher tries to remedy the poor economic situation of the country and presents a project of economic development in which the establishment of the state bank, boosting of the economy and the introduction of paper money play the central role. The similarities of his stance in the work and his theoretical assumptions found in the Notebooks, the Principles, or the Dialogues, are easily discernible. In his comments on the equivalent value of precious metal and banknotes and, finally, entries in the bank account, one can find an analogy with his immaterialistic thesis which made him famous in the early years. It is equally easy to recognise the call for entrepreneurship and the criticism of mercantilism as an economic counterpart of the thesis that activity is only reserved for finite spirits. That is also the reason for Berkeley's claim that money has no intrinsic value other than facilitating industry,

1 The first significant work raising this question was a monograph by G. A. Johnson, The Development of Berkeley's Philosophy (1923).

2 B. Belfrage, "A paradigm shift in George Berkeley's philosophy 1707-1709", Revue philosophique de la France et de l'étranger, vol. 135, 2010/1, pp. 71-82; idem, "The clash in semantics on semantics in Berkeley's Noteboook A", in: George Berkeley. Essays and Replies, Dublin: Irish Academic Press and Hermathena, 1986, pp. 117-126.

3 T. Airaksinen, "The Path of Fire: The Meaning and Interpretation of Berkeley's Siris", in: S. H. Daniel (ed.), New Interpretations of Berkeley's Thought, Amherst, New York: Humanity Books, 2007, pp. 269-271; idem, "Light and Causality in Siris", in: T. Airaksinen, B. Belfrage (eds.), Berkeley's Lasting Legacy: 300 Years Later, Newcastle upon Tyne: Cambridge Scholars Publishing, 2011, pp. 91-120; idem, "The Chain and The Animal: Idealism in Berkeley's Siris", in: S. Gersh, D. Moran (eds.), Eriugena, Berkeley, and the Idealist Tradition, Notre Dame IN: University Press of Notre Dame, 2006, pp. 226-227.

4 In this respect one of the issues discussed is the status of invisible fire which can hardly be inscribed in the early distinction between active sprits and passive ideas. See: L. Downing, "Siris and the Scope of Berkeley's Instrumentalism", The British Journal for the History of Philosophy 3 (1995), pp. 279-300. 
the economic counterpart of the activity understood as the essence of human beings.

Nevertheless, the comparison of the abovementioned early social writings with writings including the Querist allows formulating a thesis of a change in his approach towards social issues. Unlike Daniel Flage who in his recent monograph pointed out that, in connection with An Essay Preventing the Ruins of Great Britain, the Querist offers a consistent programme, I shall argue that the discrepancies between these works are greater as well as more radical than "a difference of emphasis", and consist in much stress put on the role of money, or on economic issues in general. ${ }^{5}$ At the same time, I aim to show that whereas the Querist is a much more in-depth study than the Essay containing only a few vague remarks on economy ${ }^{6}$, they differ in several aspects relating to the understanding of society. The most significant ones include Berkeley's abandoning the view that the only factor that shapes the society is rational legislation, the transition from simplistic, mechanistic understanding of the community for the benefit of adopting a more organicist vision of it, and finally: the departure from a totally dogmatic understanding of religion and adopting an attitude characterised by greater tolerance. Unlike the Essay, the Querist not so much praises the distant, unsoiled past of "natural simplicity and common sense of the English", as it seeks to change the Irish customs so that their own activity brings the country out of the economic and cultural collapse. The understanding of human activity changes as so does the vision of the world that is no longer a ready-made, God-created work whose perfection can only be destroyed by human madness, and which becomes a dynamic whole, perfected by man. Evidence for this change of views concerning both social philosophy and the philosophy of nature, can be found in the Querist, but also in two other later works by Berkeley: Siris and, partially, the Alciphron.

5 D. Flage, Berkeley, Cambridge-Malden: Polity, 2014, p. 169.

6 Detailed analyses of Berkeley's solutions concerning Ireland's economics can be found in the studies by P. Kelly (e.g. "Ireland and the Critique of Mercantilism in Berkeley's Querist", in: George Berkeley. Essays and Replies, pp. 101-116; "Berkeley's economic writings", in: K. Winkler (ed.), Cambridge Companion to Berkeley, Cambridge-New York: Cambridge University Press, 2005, pp. 339-368; “Berkeley's Querist: ,Hints... what is to be done in this Critical State of our Affairs' or proposals for a Hyperborean Eutopia?", in: R. Brook, B. Belfrage (eds.), Bloomsbury Companion to Berkeley, London-Oxford-New York-New Delhi-Sydney: Bloomsbury Publishing, 2017 (forthcoming). Berkeley's economic ideas were critically scrutinised with a reference to similar projects referring to Scottish eighteenth economy by P. Hanczewski in his article "Learning from Scotland's problems: George Berkeley and his 'Plan' for Ireland", Ruch Filozoficzny, Vol 71, No 4 (2015), pp. 129-133. 


\section{Textual Evidence of the Change}

Berkeley advocated modesty and simplicity of customs as early, as in the Essay. He recalled with horror the fact of wasting money on luxury, cashing out to import luxury goods, and wrote with repulsion about the annual masquerades. Instead, he urged the "simplicity of manners," which is a value superior to "all our riches" (ER; W: VI, 75) ${ }^{7}$, and added that "frugality of manners is the nourishment and strength of bodies politic" $(E R ; \mathrm{W}: \mathrm{VI}, 74)$. However, these remarks reveal nothing beyond the common-sense approach, typical of an eighteenth-century moralist and clergyman. It is hardly surprising that the same theses are found in the later Querist, where he equates the wasteful country to a matron spending money on her own pleasures instead of feeding her own children (Querist, 179; W: VI, 119), and where gambling is still condemned. It's too easy a way to achieve wealth, too risky, having nothing to do with diligence and a practice which overly kindles human passions. In fact, for Berkeley it is nothing else but madness. The way to improve the situation is to introduce a gradual change of customs. The desire to live in luxury should be restrained (Querist, 167-171; W: VI, 118-119), even by considering the replacement of imported goods with those produced locally. However, it is possible not only through top-down legal regulations, but above all by shaping appropriate attitudes and using human passions. Fashion and human vanity often lead to fatal results (nine-tenths of imports are luxury goods, Berkeley estimates), but if they are well targeted, they may be salutary: "Whether customs and fashions do not supply the place of reason, in the vulgar of all ranks? Whether, therefore, it doth not very much import that they should be wisely framed?" (Querist, 16; W: VI, 106). So it is not about the eradication of fashion but about shaping it accordingly, which is where Berkeley sees the role of legislation. Berkeley rhetorically asks whether "Vanity and luxury of a few ought [not] to stand in competition with the interest of a nation? (Querist, 167; W: VI, 118) and "Whether a woman of fashion ought not to be declared a public enemy?" (Querist, 147; W: VI, 117), but at the same time proposes to find ways of satisfying human ambitions that would contribute to an economic development (for example, when wealthy people can stand out

7 The references to the works by Berkeley according to Luce and Jessop edition (The Works of George Berkeley, A. A. Luce, T. E. Jessop (eds.), London: Thomas Nelson, 1948-1957; hereafter W) include the volume number and the page number. In the case of the Querist also the number each query is added, according to this edition. However, the comparison of the earlier and the later editions of the work was possible only on the ground of the new, far more detailed edition prepared by B. Belfrage (not published yet). I am much grateful to prof. Belfrage for the possibility to refer to it while preparing this paper. 
by possessing beautiful homes and gardens (Querist, 121; W, VI, 115 and 396; W: VI, 137). Since, as he writes, "Whether vanity itself should not be engaged in this good work?" (Querist, 361; W: VI, 135)

The need to "feed the hungry and clothe the naked" as Berkeley writes in his Advertisement, is compelling not only because of Christian charity directed at people suffering from hunger and deprivation. Indeed, it is accompanied by the belief that the impairment of this group has a direct impact on the functioning of the whole of society. Hence, the comparison of a community to an organism or a family enables Berkeley to write, "When the root yieldeth insufficient nourishment, whether men do not top the tree to make the lower branches thrive?" (Querist, 158; W: VI, 118). "Whether the natural body can be in a state of health and vigour, without a due circulation [in] the extremities, even in the fingers and toes?" (Querist, 484; W: VI, 145) asks Berkeley and adds, "Whether, although the capilary vessels are small, yet obstructions in them do not produce great chronical diseases?" (Querist, 580; W: VI, 153)

Since the country is a whole, the problem that remains is the relationship between the Catholic and Protestant communities. If we compare the earlier editions of the Querist issued from the late 1930s as well as later ones from the early 1950s, we will see a certain evolution of Berkeley's views. Berkeley does not only write of Ireland as of his own country, which, while being subordinate to England (Querist, 3:97; W: VI, $175)^{8}$, is to constitute a self-contained state organ, where a closed inn is to provide comfort to its inhabitants; in later editions however, the query speaking of the Protestant Colony is removed (Querist, 3:78; W: VI, 174). Moreover, other entries in which Berkeley uses a rather contemptuous term "papists" (Querist, 1-293-304; W: VI, 160-161; 2:37; W: VI, 162) are removed, and instead he refers to them as "Catholics" (Querist, 257; W: VI, 126) allowing also for the possibility of their studying at a college without obliging them to attend chapel-duties, catechisms, or divinity lectures (Querist, 191; W: VI, 120).

What matters here is that the three perspectives from which Berkeley views the community, i.e. the use of human passions to shape the right attitudes, the organicist vision of the community, and the necessity of arranging coexistence between the Protestant minority and the Irish Catholic majority, did not appear in earlier writings. When Berkeley asks in the Querist, "Whether in any order a good building can be made

8 Belfrage's edition is based on the first publication of the Querist and marks all the changes in subsequent editions. Thus, one can follow the evolution of the text, also deletion or insertion of some of the queries. In the Luce and Jessop edition, however, it is hard to recognise the process, since all the queries missing in the last edition appeared during Berkeley's lifetime are gathered in three groups referring to three following parts of the work and entitled invariably as "Queries omitted". 
of bad materials? Or whether any form of government can make a happy state out of bad individuals?" (Querist, 201; W: VI, 122), this question seems to reflect the possibility of changing the habits of ordinary Irish people and creating a cohesive community. The measures presented in An Essay Towards Preventing the Ruin of Great Britain are much simpler, not only because Berkeley to such a small extent draws the attention to specific economic issues and limits himself to several hints such as the imposition of additional taxes from which houses could be maintained, roads built or rivers made navigable (ER; W: VI, 72). A more important circumstance influencing the solutions proposed therein is the attachment to the dogmatic religious attitude that we find earlier in the Passive Obedience. God's commandments revealed by the reason do not allow for exceptions and their value is manifested in the timeless order of morality and in the perspective of eternity. As he writes, "The same atheistical narrow spirit, centring all our cares upon private interest, and contracting all our hopes within the enjoyment of this present life, equally produceth a neglect of what we owe to God and our country" (ER; W: VI,79). Thus, there is a choice, rational and religious behaviour in the perspective of eternity or diving into the «enjoyments of this present life" and atheism dissuading people from an involvement in pro-social activities. Tertium not datur.

Identified with the imperatives of reason, the dictates of God/s will at the same time constitute the basis of legislation. The obedience to law is fundamentally exceptionless and law is seen as the best instrument for putting these orders into effect. This, in turn, is the reason why morals should be severe and why appropriate legal solutions should be established, from the introduction of «sumptuary laws», through the imposition of taxes, to «an absolute prohibition of those [public diversions] which have a direct tendency to corrupt our morals, as well as by a reformation of the drama» (ER; W: VI, 79).

In the Essay, we will not find yet any remarks which may indicate an organicist understanding of the community. Berkeley seems to be attached to thinking about the community in dichotomous categories "the ruling - the subjects» in which the first are equipped with reason, the other dispose of physical force. He treats religious issues in an equally rigorous manner pointing to the superiority of Protestantism over papacy. Indeed, he writes that atheists and people who oppose Christianity in general should be stigmatised, while the common sense and the mercy of the Christian religion prohibit him from being a zealous fanatic and acting against those "who differ from us in some points of religion» $(E R ; \mathrm{W}: \mathrm{VI}, 70)$. However, the remarks about the corruption of customs that occurred during to the reign of Charles II could concern both with the departure from the Puritan harshness of the times of the Republic, as well as his religious tolerance manifested in the Declaration of Indul- 
gence of 1672. Also reading that postulating the erection of monuments commemorating crimes against the state which would serve as a warning to others has an appropriate implication, since, according to Berkeley, the only monument that was erected was the Monument commemorating the great fire of London, which, in concord with the conviction of the time, was to have been deliberately started by Catholics.

\section{From Naivety to Realism. The Querist and the Evolution of Berkeley's Views}

It should be assumed that An Essay Towards Preventing the Ruin of Great Britain belongs to an early stage of Berkeley's social views development, as this is where he develops the theses of his earliest moral treatise, Passive Obedience. They can be summarised as follows:

$1 \mathrm{a}$. The moral value of deeds consists in the compliance of the maxim underlying them with the law established by God and the resulting statute laws. Because these laws can only be discovered by reason, morality can be based only on the principles of reason.

"A conformity to His will, and not any prospect of temporal advantage, is the sole rule whereby every man who acts up to the principles of reason must govern and square his actions." (PO, 6; $\mathrm{W}$ : VI, 20)

2 a. The universal observance of God's laws leads to the public good, that is, the well-being of mankind.

"The observation of some determinate, established laws, which, if universally practised, have, from the nature of things, an essential fitness to procure the well-being of mankind." ( $P O, 8$; $\mathrm{W}$ : VI, 21) "These laws have a necessary tendency to promote the well-being of the sum of mankind, taking in all nations and ages, from the beginning to the end of the world." (PO, 10; W: VI, 22)

$3 \mathrm{a}$. The moral value of deeds is independent of the natural good (happiness) of individuals.

"He who squares his actions by this rule can never do amiss, though thereby he should bring himself to poverty, death, or disgrace: no, not though he should involve his family, his friends, his country, in all those evils which are accounted the greatest and most insupportable to human nature." (PO, 13; W: VI, 23).

$4 \mathrm{a}$. The combination of the virtue resulting from respecting the law and individual happiness can only take place in future life - the reason that in the earthly life must take precedence over senses can reconcile with them only in the perspective of eternity. 
In the Essay, the whole whose well-being constitutes the supreme goal, is the "nation," whilst the realisation of that goal consists in the proper use of freedom of intelligent beings; a betrayal of the principles of freedom through the pursuit of a private interest (egoism) or surrendering to passions means licentiousness (ER; W: VI, 70) and leads to the collapse of the country, the best way towards which is through gambling and speculation. Reasonable freedom is realised in several ways, depending on the use people make of their reason. Such freedom manifests itself through the establishment of law that implements the decree of God and, by respecting it, and is based on understanding the general purpose pursued by it or by passive obedience of the subjects. In all cases, the moral value of deeds is concerned with the causes of such deeds (their being subordinate to general law) rather than direct consequences, especially for individuals. "For though we may attempt to patch up our affairs, says Berkeley, yet it will be to no purpose; the finger of God will unravel all our vain projects, and make them snares to draw us into greater calamities" (ER, 7; W: VI, 71).

In economic terms, being rationally guided by the public good is possible by introducing the laws regulating the economy, i. e. by redistributing money so as to contribute to the improvement of the overall economic situation (mainly through fiscal policy: taxes for the poor, luxury tax, travellers, and the "dead bachelors" tax, prohibition of sumptuous parties) and to Great Britain becoming independent of foreign trade (this theme will reappear in the Querist). Therefore, we can extend the above principles from the Passive Obedience with further ones which constitute their equivalents in the Querist:

$1 \mathrm{~b}$. Following the reason should be contraposed with passions: "even benevolence, more dangerous than other passions is... apt to dazzle the mind with the appearance of goodness and generosity" $(P O, 13$; $\mathrm{W}$ : VI, 23); the pursuit of excessive luxury is vicious and ruins the nation (ER; W: VI, 71).

$2 \mathrm{~b}$. The public good also means a good functioning of the economy as a whole by "ridding our streets of beggars" and "the public receiving no small advantage from the industry of those, who are now so great a burthen and expence to it" (ER; W: VI, 72).

$3 \mathrm{~b}$. Acting for the economy (natural good) as a whole has moral value; it is not aimed at achieving the natural good (e.g. wealth) by individuals.

$4 \mathrm{~b}$. A proper moral attitude should be characterised by religiousness and restraint as well as acting for the benefit of the whole community. In the end, the natural good of an individual (which in the economic sense is equivalent to prosperity) is contrasted with the moral good. 
In turn, only acting for the good of the whole is moral and religious: "a sense of public spirit" requires "a true sense of religion" (ER; W: VI, 79). Only then can one expect that "men of money [will] make free gifts, or lend it without interest to their country" (ER; W: VI, 82). Compared to this rather dreamy vision, the Querist is much more realistic not only because of more accurate economic analyses but also because it more accurately depicts the mechanism of human motivation. Hence, based on the above-mentioned equations between the two writings, we may provide counterparts of the previous rules derived from the Querist:

$1 \mathrm{c}$. The factors motivating human actions are reason and passions; however, the effect of the latter can be used to the advantage of the community by creating the right trend and influencing :human ambitions. A new motivating factor is the respect for the opinion of others, as well as the realisation of the natural good - happiness and prosperity in temporal life.

2 c. The public good cannot be separated from the good of particular individuals. Thus, there is no longer a strong opposition of an action directed towards oness own good and an action directed at the good of the whole and thus having moral value.

$3 \mathrm{c}$. It is not enough to remove the beggars from the streets. Poverty and beggars are to disappear from the streets; however, they are to disappear clothed and fed and, above all, motivated to work.

$4 \mathrm{c}$. The organicist relationship between members of the community is emphasised. Berkeley returns to his earlier view that comprehensive knowledge of the ways of achieving the public good is given only to few and equates the aristocracy to the reason, whereas the lower classes to the will. Therefore, he assigns each of them a different task: the former are to create laws and institutions and supervise the results of work of the latter. In the Essay, the purpose of the said activities is the good of the whole community, whilst the good of its individual members can only result from it. The same applies to morality and economy. Again, we go back to the theses found in the Passive Obedience: Moral actions are such actions that, if commonly practised, lead to the good of the whole human community. In the Essay, a good economic situation is the condition for an improvement of the fate of individual people. Hence, the writing praises the French nobility dependence on the royal authority by leading it towards impoverishment (ER; W: VI, 76-77) and the requirement that rich people give money to the state. In the Querist, the situation is reversed, i.e. only the affluence of individual people: peasants who have food and clothes and wealthy gentry engaged in improving the country fate, testifies to the states $\mathrm{s}$ wealth. The first case refers to a single change, the second to a slow evolution. 
It is also connected with Berkeley>s new approach to time. The Essay deals with two plans: the eternity of religious and moral imperatives, and the earthly world in which human madness has led to corruption and the country found itself at the edge of the abyss. This historical time does not extend far: Berkeley considers the possibility of the existence of a three stage social institutions development, i.e. "growth, perfection, and decay" (ER; W: VI, 85) and contrasts the unblemished past inhabited "by a religious, brave, sincere people" (ER; W: VI, 74) with the depravity observed by him as "our Infidels have passed for the gentlemen, and our venal traitors for men of sense who knew the world" (ER; W: VI, 84). The present collapse is the opposite of the past inhabited by ancient Greeks and Romans but also by noble Englishmen filled with "natural plainness and good sense" (ER; W: VI, 76). It is hardly surprising that the remedy is an attempt to revive this mythical golden age by "erecting an academy of ingenious men whose employment it should be to compile the history of Great Britain, to make discourses proper to inspire men with a zeal for the public, and celebrate the memory of those who have been ornaments to the nation, or done it eminent service" (ER; W: VI, 81). The golden age has passed, the time of collapse has begun.

In the Querist, the situation changes significantly. Academies aiming to preserve the memory of the good times unblemished by human madness give way to schools of arts and crafts, education is to be practical and have a broader character. This means not only greater realism and pragmatism, but also a change in the time perspective: many of Berkeley>s solutions emphasise the future as well as slow evolutionary transformations that lead to an improved economic situation. The improvement is not to occur with a single legal decree, it is not to happen in a few years time during which tax revenue will give people work. The picture is no longer black-and-white but rather more nuanced, and possible changes are more extended in time. While one still finds references to the past, this time they concern the "natural Irish" (Querist, 512; W: VI, 147) and "old native Irish being "most indolent and supine people in Christendom" (Querist, 357; W: VI, 134), whose sluggishness should be overcome, possibly by awakening industriousness and resourcefulness in them. Amongst human attitudes, atheism and lack of respect for social welfare on the one hand, and the religious and social zeal on the other, constitute no more than the most extreme bearings. Between them, there is room for human imperfection, human vices, and a whole variety of attitudes and actions that are not necessarily opposed to morality. 


\section{Further Evidence of the Evolution}

The hypothesis of Berkeley's social views evolution can be reinforced if the Querist is juxtaposed with the Alciphron (1732). According to the interpretation suggested here, together with the Alciphron, the earlier social views become outdated (including also the Passive Obedience, An Essay Towards Preventing the Ruins of Great Britain and the Proposal), whereas the changes that I mentioned result from his reflections on the issues contained therein.

Found in the second and third dialogue of the work, Berkeley's ferocious attack on Bernard Mandeville, the author of the notorious Fable of the Bees (1714) and Shaftesbury, whose Characteristics of Men, Manners, Opinions, and Times (1711) had a strong deistic character, apart from the accusations of spreading the irreligiousness destructive for the country, was due to several specific reasons. Mandeville's concept of economic egoism praises economic activity aimed at bringing profits to individuals without regard for social welfare. Such welfare, other than the good of individual people, proves to be illusory, and striving for it is not only devoid of the moral value, but also simply stupid. Hence Mandeville's praise of the generally disapproved human behaviour, such as gambling or drunkenness, summarised in the saying, "vice then a fine thing with an ugly name" (Alciphron, 2, 3; W: III, 69). Berkeley formulates a series of allegations against it, inter alia a) underestimating the costs of the actions since the loss caused by them is not matched by their potential profit, $b$ ) undermining of the foundations of the whole existing legal and moral order by 'a new experiment' negating the notion of virtue, and c) self-contradiction of Mandeville's theory: deists (who de facto are crypto-atheists, as they stand against all religious superstitions) seem to hold that the individual interests of people will be, in some unknown way, harmonised and thus they will contribute to the overall public good. It is hard to overestimate the passion with which Berkeley objects the scourge of alcohol addiction - in the Alciphron, the Querist, and in Siris. Nevertheless, two entries in the Querist appear to be a correction of the previous stance: reaching for alcohol, though reprehensible, may be acceptable if it can bring economic benefits (Querist, 113, 156, 157; W: VI, 114, 118). This does not mean cynicism or cold economic calculation; however, natural goods identified with the economic growth are no longer contrasted with the moral good with the same severity as in earlier works.

A similar matter is concerned with the rethinking of Shaftesbury's standpoint whom in the Alciphron Berkeley accuses of following fashion and the commonly shared opinion which is too labile an attitude for building any morality on it. The approval of others is not sufficient 
to develop a solid foundation so that it could become a source of moral deeds even when the said approval is not given. Emotional bonds connect people only in small groups, thus the moral sense, based on honour, is difficult to distinguish from the honour of a thief, gambler, or drunkard (Alciphron, 3, 2; W: III, 114). If natural benevolence is to be impartial, Shaftesbury must remain a devotee of "heroic virtue" to which very few can bring themselves. Noticeably, in the meantime, in the Querist he strives to identify the means to stimulate the human industry also through setting trends and stimulating the ambition. The comments contained in his letters to Prior indicate that one of the factors motivating to take action is the sympathy for the sick and poor, whose "distresses are endless". ${ }^{9}$ It is hard to imagine at the same time that Berkeley could subscribe his name, without a trembling hand, to his own words from the Passive Obedience, proclaiming that "tenderness and benevolence ... like all other passions, must be restrained and kept under ... [being] more dangerous than other passions, insomuch as they are more plausible, and apt to dazzle and corrupt the mind with the appearance of goodness and generosity» $(P O, 13 ; \mathrm{W}: \mathrm{VI}, 23)$.

The mentioned changes can also be seen in other works by Berkeley. The religious dogmatism of thinking only in terms of the common good (the good of the state or the whole religious community) is found, inter alia, in A Proposal for the Better Supplying of Churches in our Foreign Plantations (1724). The efforts to promote Christianity in America are an attempt to return to nature and the past unblemished with bad customs, which corresponds to the early stages of development in his views. Berkeley does not hesitate to suggest that young Indians be kidnapped to become good propagators of Christianity, so that Anglicanism could put an end to papacy promulgated in America by French missionaries through captivating Indian children (Proposal; W: VII, 347), which is synonymous with the dogmatic identification of the common good in the religious and political dimension.

\section{Conclusions}

The comparison of Berkeley's social views allows drawing two conclusions. The first one concerns the change in his attitude towards society: he discloses a deeper insight not only into economic issues, but also into factors shaping human behaviour within its bounds. Moreover, though still convinced of the crucial role of religion in establishing the wellbeing of society, Berkeley seems to lose his sternness and adopts more tolerant views towards Catholics.

\footnotetext{
9 Letter to Prior, May 19, 1741 (W: VIII, 251).
} 
The second conclusion is more general. One of the arguments for the constancy of Berkeley's philosophy is the interdependence of his theoretical philosophy and his social theory. The analyses of his writings support the thesis that such bonds exist, but this does not provide a sufficient proof for the claim of the constancy and invariability of his views. If one were to look for correspondences between Berkeley's social views and his metaphysics, some of the entries added in the late edition of the Querist seem to be in harmony with the new metaphysics of light contained in Siris, rather than the natural philosophy known form the early works. No longer is the world perfect, and no longer is the evil touching people only a necessary ingredient meant to diversify it. In the Principles Berkeley wrote of "the very blemishes and defects of nature" which "are not without their use, in that they make an agreeable sort of variety, and augment the beauty of the rest of the Creation, as shades in a picture serve to set off the brighter and more enlightened Parts." (Principles, 152; W: II, 111) Now, the "pure, invisible fire" permeates all bodies and as the "vital flame" (Siris, 201; W: V, 100) animates all the Creation, which is not yet fully formed, but still forming itself under the guidance of the Providence (Siris, 233; W: V, 111). That invisible fire is a factor that dynamises the whole of the Creation. The certainty that the Creation as a whole is perfect disappears but from a temporal human perspective - also the perspective of the «naked, poor, and sick» - the world is just getting better. As Berkeley writes, «Natural productions, it is true, are not all equally perfect. But neither doth it suit with the order of things, the structure of the universe, or the ends of Providence, that they should be so. ... From the constant observation of such rules, natural evils will sometimes unavoidably ensue; things will be produced in a slow length of time, and arrive at different degrees of perfection» (Siris, 256; W: V, 121-122). In the world, in which nothing is "perfect under the sun" and in which "a State or Body-Politic" should be compared to "the human body, which lives and moves under various indispositions, perfect health being seldom or never to be found" (Querist, 343; W: VI, 133), only people engaged in the gradual improvement of their society can be benevolent physicians" (Querist, 344; W: VI, 133). This idea of the nonperfect world which can only be improved is a new motif which cannot be found in the early writings by Berkeley.

\section{Bibliography}

Airaksinen, T. "Light and Causality in Siris". In T. Airaksinen, B. Belfrage (eds.) Berkeley's Lasting Legacy: 300 Years Later. Newcastle upon Tyne: Cambridge Scholars Publishing, 2011, pp. 91-120. 
Airaksinen, T. "The Chain and The Animal: Idealism in Berkeley's Siris". In S. Gersh, D. Moran (eds.) Eriugena, Berkeley, and the Idealist Tradition. Notre Dame IN: University Press of Notre Dame, 2006, pp. 226-227.

Airaksinen, T. "The Path of Fire: The Meaning and Interpretation of Berkeley's Siris". In S. H. Daniel (ed.) New Interpretations of Berkeley's Thought. Amherst, New York: Humanity Books, 2007, pp. 269-271.

Belfrage, B. "A paradigm shift in George Berkeley's philosophy 1707-1709". Revue philosophique de la France et de l'étranger, vol. 135, no. 1 (2010), pp. 71-82.

Belfrage, B. "The clash in semantics on semantics in Berkeley's Noteboook $A^{\prime \prime}$. In D. Berman (ed.) George Berkeley. Essays and Replies, Dublin: Irish Academic Press and Hermathena, 1986, pp. 117-126.

Downing, L. "Siris and the Scope of Berkeley's Instrumentalism". The British Journal for the History of Philosophy 3 (1995), pp. 279-300.

Flage, D. Berkeley. Cambridge - Malden: Polity, 2014.

Grzeliński, A. "From the 'Querist' to 'Siris' and Back. Berkeley's Social Philosophy 1737-1752". Ruch Filozoficzny, vol. 71, no. 4 (2015), pp. 155-169.

Hanczewski P. "Learning from Scotland's problems: George Berkeley and his 'Plan' for Ireland". Ruch Filozoficzny, vol. 71, no. 4 (2015), pp. 129-143.

Johnson, G. A. The Development of Berkeley's Philosophy, London: Macmillan, 1923.

Kelly, P. “Berkeley's economic writings". In K. Winkler (ed.) Cambridge Companion to Berkeley, Cambridge-New York: Cambridge University Press, 2005, pp. 339-368.

Kelly, P. "Berkeley's 'Querist' : ,Hints... what is to be done in this Critical State of our Affairs' or proposals for a Hyperborean Eutopia?". In R. Brook, B. Belfrage (eds.) Bloomsbury Companion to Berkeley. London - Oxford New York - New Delhi - Sydney: Bloomsbury Publishing, 2017.

Kelly, P. "Ireland and the Critique of Mercantilism in Berkeley's Querist". In George Berkeley. Essays and Replies, pp. 101-116.

Luce A. A., Jessop T. E. (eds.) The Works of George Berkeley. London: Thomas Nelson, 1948-1957.

Olscamp, P. J. The Moral Philosophy of George Berkeley. The Hague: Martinus Nijhoff, 1970.

Szymańska-Lewoszewska, M. "Religion and Politics George Berkeley's Understanding of Ireland's Wellbeing in Early and Late Editions of 'The Querist'”. Ruch Filozoficzny, vol. 71, no. 4 (2015), pp. 113-128. 


\section{Summary}

\section{The Querist and the Development of George Berkeley's Understanding of Society}

The late editions of the Querist (1737-1750) appeared almost 40 years after George Berkeley published his Passive Obedience (1712) and almost 30 after An Essay Preventing the Ruin of Great Britain (1721), the first of his writings dealing with the problems of Ireland's economy. During the period similar issues were raised in at least two of Berkeley's writings, namely A Proposal for the better Supplying of Churches in our Foreign Plantations (1724), and the Alciphron (1732). The differences between the earlier writings and the Querist, as well as between the earlier and the later editions of the latter work, allow posing a thesis concerning the development of Berkeley's understanding of the society and its relation to morality and religion. The change refers to an organistic conception of the society, a deeper understanding of non-rational factors shaping human behaviour, and a greater tolerance for Catholics. This new position is seconded by a new approach to nature which no longer is a perfect whole.

\section{Keywords}

George Berkeley, the Querist, British empiricism, $18^{\text {th }}$-century Ireland, social philosophy 